\title{
Rapid Assessment of Sea Turtle and Marine Mammal Bycatch in the Union of the Comoros
}

\author{
CNS Poonian ${ }^{1,2}$, MD Hauzer ${ }^{2}$, A Ben Allaoui ${ }^{3}$, TM Cox $^{4}$, JE Moore ${ }^{5}$, AJ Read ${ }^{5}$, RL Lewison 6 , LB \\ Crowder $^{5}$ \\ ${ }^{1}$ Community Centred Conservation (C3), 17 Northcliffe Drive, London, UK, N20 8JX; ${ }^{2}$ C3-Comores, BP \\ 8310, Moroni, Grande Comore, Union of the Comoros; ${ }^{3}$ Direction Nationale des Ressources Halieutiques - \\ Ministère du Développement Rural de la Pêche, de l'Artisanat et de l'Environnement, Union des Comores; \\ ${ }^{4}$ Savannah State University, Savannah, Georgia, USA $;{ }^{5}$ Center for Marine Conservation, Duke University \\ Marine Laboratory, Beaufort, North Carolina, USA; ${ }^{6}$ Department of Biology, San Diego State University, San \\ Diego, California, USA
}

Keywords: Bycatch, Artisanal fishing, Comoros, Turtle, Cetacean, Incidental capture

\begin{abstract}
The Union of the Comoros is host to internationally-significant populations of sea turtles, dugongs and cetaceans, all of which are potentially threatened by incidental catch in artisanal fishing gears. This work presented here was part of a larger initiative, known as Project GloBAL (Global Bycatch Assessment of Long-lived species), to evaluate artisanal fishing effort and bycatch of sea turtles and marine mammals in data-deficient areas. Questionnaire surveys were conducted with 409 out of the estimated 8,500 artisanal fishers in the Comoros, on the islands of Grande Comore (25/44 landing sites) and Mohéli (5/13 landing sites). Sea turtles (mainly Chelonia mydas) were reportedly captured in large numbers, although it was not always clear if captures were accidental or deliberate. Lower rates of turtle capture were reported from Mohéli, possibly as a result of awareness-raising activities associated with Mohéli Marine Park. Gillnets presented the most serious bycatch-related threat to dugongs (Dugong dugons) and current mitigation efforts such as closed areas to limit gillnet use are essential for the continued presence of this species in the Comoros. Cetaceans were rarely captured and mortality was reportedly low; with spinner dolphin (Stenella longirostris) the most common of several species recorded as bycatch.
\end{abstract}

\section{INTRODUCTION}

Incidental catch in commercial fishing gears poses a serious threat to many sea turtle and marine mammal populations (Lewison et al., 2004), but the impacts of bycatch in small-scale artisanal fisheries is relatively unknown. The present study was part of an international initiative, coordinated by Project GloBAL (Global Bycatch Assessment of Long-lived species), to develop and test a rapid assessment protocol to quantify artisanal fishing effort and bycatch of sea turtles and marine mammals in data-deficient areas.
The Union of the Comoros is situated at the northern end of the Mozambique Channel, equidistant from continental Africa and Madagascar. It comprises three volcanic islands: Grande Comore, Anjouan and Mohéli. The islands host a number of ecologically important and vulnerable coastal habitats including coral reefs, mangrove forests and seagrass beds (Ahamada et al., 2004; Anasse et al., 2003), which support high marine biodiversity.

Mohéli hosts one of the most important green turtle (Chelonia mydas) populations in the Indian Ocean (with an estimated 5,000 nesting females) and a smaller population ( $<50$ nesting females) of hawksbill turtles (Eretmochelys imbricata) 
(Ben Mohadji and Paris, 2000). These species are Endangered (Seminoff, 2004) and Critically Endangered (Mortimer and Donnelly, 2008), respectively. Smaller numbers of green turtles ( $<50$ nesting females) also nest on Anjouan or Grand Comore (Ben Mohadji and Paris, 2000; Mortimer, 1993). The hunting and trade of marine turtles is prohibited by Comorian law, but turtles are still hunted for their meat (Hauzer et al., 2008). A National Turtle Conservation Action Plan (Ben Mohadji \& Paris, 2000) has been completed but not fully implemented apart from through a few community-based projects (Ahamada, 2001; C3Comores, 2007). Although the National Turtle Conservation Action Plan did not recognize bycatch as a threat, accidental capture of immature turtles in nets has been reported (Mortimer, 1993).

Direct hunting of dugongs (Dugong dugon) in the Comoros was a problem in the past, but the key contemporary threat is accidental capture in gillnets (Alfthan \& Davis 2006; Davis \& Poonian 2007; Fatouma, 2004). Data from incidental sightings indicate that dugongs are extremely rare and restricted primarily to Mohéli (Fatouma, 2004). Few scientific studies of cetaceans have been conducted in the Comoros, although thirteen species have been reported in the area (Kiszka $e t$ al., 2006).

\section{MATERIALS AND METHODS}

Turtle and marine mammal bycatch in artisanal fisheries in the Comoros was investigated using structured interviews of fishers and analysis of existing fishery data. A total of 25 out of 44 landing sites were sampled on Grande Comore and 5 out of 13 sites were sampled on Mohéli (all outside Mohéli Marine Park) (Figure 1). Anjouan was omitted from the sampling because of political unrest. Sites were selected using stratified sampling with strata based on the number of boats at each village (determined from UNEP, 2002) to achieve a geographically representative sample from each island and to include both large ( $>50$ boats) and small ( $<50$ boats) fishing communities.

Fishers were questioned about their boat and gear characteristics, fishing patterns and incidence of bycatch (See Appendix 1 for questionnaires). An identification guide (Richmond, 2002) was shown to interviewees to assist in bycatch species identification. Fishers were interviewed individually, and, since landing sites were small, often every fisher at a given site was interviewed. At times, specific fishers were selected for interview (e.g. senior and/or experienced fishers). Between June and August 2007, a total of 409 interviews (200 short and 140 long interviews on Grande Comore; 34 short and 35 long on Mohéli) were conducted out of the estimated 8,500 fishers in the Comoros (Union des Comores, 2005).

\section{RESULTS AND DISCUSSION}

Reported boat specifications were similar on both islands, although boats used on Mohéli tended to be larger and motorized boats had larger engines compared to those on Grande Comore (Table 1). It was noticeable that motorized boats were much more frequent than in previous surveys reported by Abdoulhalik, 1998: an increase from $25 \%$ to $40 \%$ and from $32 \%$ to $52 \%$ on Grande Comore and Mohéli, respectively. Hook and lines, targeting pelagic fish, were the most common fishing gear used on both islands (Table 1). On Grande Comore, line fishing was conducted on a larger scale, with fishers using multiple (up to 180) hooks on each line. The gear represents what is commonly referred to as a 'longline'. Gillnets targeting reef fish were more frequent on Mohéli (Table 1). Fishers on Grande Comore spent more time at sea than their Mohélian counterparts, and most fishers were fulltime (Table 1). The Kashkazi season (NovemberMarch) was regarded as the best season for fishing by Grande Comorian fishers, but fishers on Mohéli had no clear preference between the Kashkazi and M'beni season (September-October) as shown in Table 1.

Annual turtle captures, both accidental and deliberate, were more frequently reported on Grand Comore than on Mohéli and green turtles were the most commonly captured species: $76 \%$ on Grande Comore and $89 \%$ on Mohéli (Table 2). It was not always clear during the interviews as to whether turtles caught were captured accidentally or intentionally. Accidental catches might come about from attraction of turtles to the bait and swallowing of the hook, through foul-hooking by part of the turtle body or flippers, or entanglement 

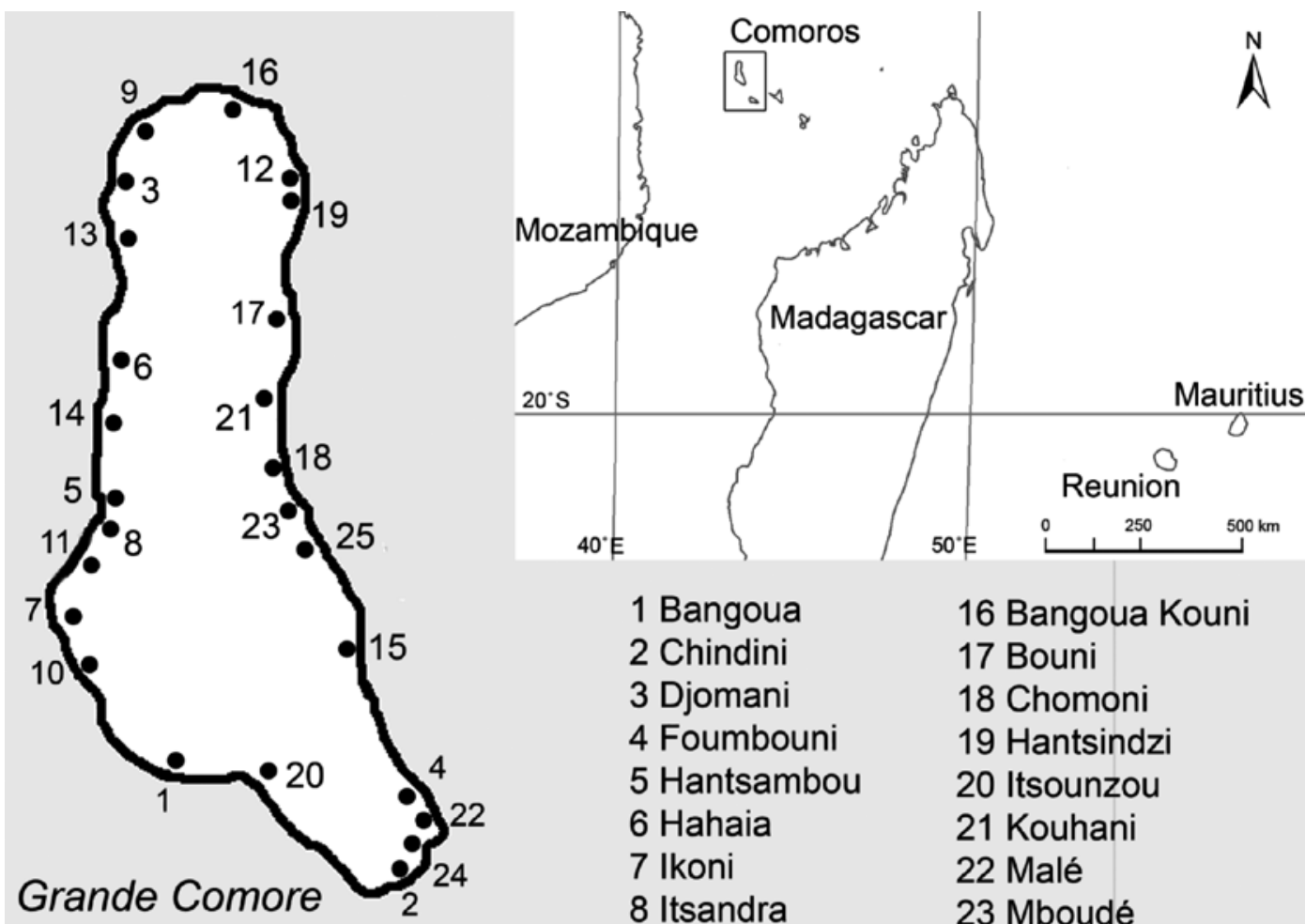

$12^{\circ} \mathrm{S}$

\begin{tabular}{ll}
1 Bangoua & 16 Bangoua Koun \\
2 Chindini & 17 Bouni \\
3 Djomani & 18 Chomoni \\
4 Foumbouni & 19 Hantsindzi \\
5 Hantsambou & 20 Itsounzou \\
6 Hahaia & 21 Kouhani \\
7 Ikoni & 22 Malé \\
8 Itsandra & 23 Mboudé \\
9 Mitsamiouli & 24 Ouroveni \\
\hline 10 Mouandzaza & 25 Tsangadjou \\
11 Moroni & 26 Fomboni \\
12 Ndroudé & 27 Mbatsé \\
13 Ntsaouéni & 28 Djoyezi \\
14 Vanambouani & 29 Domoni \\
15 Bandamadji & 30 Hoani
\end{tabular}

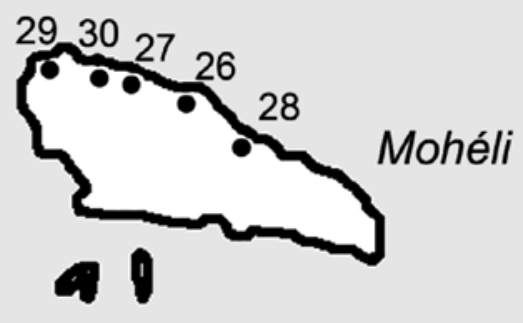

$44^{\circ} \mathrm{E}$

Fig. 1. Location of landing sites on Grande Comore and Mohéli where the survey was conducted

in the fishing line. Mortality rates are probably higher than those shown in Table 2 because turtle meat is extremely popular in the Comoros (Ben Mohadji \& Paris, 2000; Mortimer, 1993), so much of what was reported as bycatch may have been caught intentionally. Also, fishers' interpretation of an 'accidental' capture was often ambiguous (e.g. they may have reported turtle capture to be 'accidental' if catching turtles was not the main aim of the fishing trip). Awareness-raising activities on Mohéli may have helped reduce bycatch mortality and intentional capture of sea turtles, as bycatch rates were reportedly lower on that island than on Grand Comore. Alternatively, increased awareness 
Table 1. Characteristics of the artisanal fisheries on Grande Comore and Mohéli (all values are reported as mean $\pm \mathrm{SE}$ )

\begin{tabular}{lccccccc}
\hline & $\begin{array}{c}\text { Length of } \\
\text { prirogues/m }\end{array}$ & $\begin{array}{c}\text { Length of } \\
\text { motorized } \\
\text { boats/m }\end{array}$ & $\begin{array}{c}\text { Engine size/ } \\
\text { HP }\end{array}$ & $\begin{array}{c}\text { \% using } \\
\text { lines }\end{array}$ & $\begin{array}{c}\text { \% using } \\
\text { gillnets }\end{array}$ & $\begin{array}{c}\text { \% fishing } \\
\mathbf{2 6 - 3 0} \text { days } \\
\text { month }^{-1}\end{array}$ & $\begin{array}{c}\text { Preferred } \\
\text { fishing season }\end{array}$ \\
\hline Grande Comore & $\begin{array}{c}3.6 \pm 0.8 \\
(\mathrm{n}=340)\end{array}$ & $\begin{array}{c}5.3 \pm 1.3 \\
(\mathrm{n}=340)\end{array}$ & $\begin{array}{c}15.0 \pm 2.0 \\
(\mathrm{n}=140)\end{array}$ & $\begin{array}{c}97 \\
(\mathrm{n}=340)\end{array}$ & $\begin{array}{c}(\mathrm{n}=340) \\
(\mathrm{n}=140)\end{array}$ & $\begin{array}{c}\text { Kashkazi }(64 \%) \\
(\mathrm{n}=140)\end{array}$ \\
Mohéli & $\begin{array}{c}3.9 \pm 1.7 \\
(\mathrm{n}=69)\end{array}$ & $\begin{array}{c}5.9 \pm 0.8 \\
(\mathrm{n}=69)\end{array}$ & $\begin{array}{c}21.5 \pm 11.5 \\
(\mathrm{n}=35)\end{array}$ & $\begin{array}{c}91 \\
(\mathrm{n}=69)\end{array}$ & $\begin{array}{c}4.4 \\
(\mathrm{n}=69)\end{array}$ & $\begin{array}{c}29 \\
(\mathrm{n}=35)\end{array}$ & $\begin{array}{c}\text { Kashkazi }(34 \%) \\
\text { M'beni }(34 \%) \\
(\mathrm{n}=35)\end{array}$ \\
\hline
\end{tabular}

Table 2. Frequency of and mortality resulting from captures of turtles and cetaceans in artisanal fishing gear on Grande Comore and Mohéli

\begin{tabular}{lccccc}
\hline & $\begin{array}{c}\text { \% fishers } \\
\text { reporting turtle } \\
\text { captures during } \\
\text { the last year }\end{array}$ & $\begin{array}{c}\text { \% turtle mortality } \\
\text { for accidental } \\
\text { captures }\end{array}$ & $\begin{array}{c}\text { Season during } \\
\text { which turtles are } \\
\text { most commonly } \\
\text { captured }\end{array}$ & $\begin{array}{c}\text { \% fishers reporting } \\
\text { cetacean captures } \\
\text { during their } \\
\text { lifetime }\end{array}$ & $\begin{array}{c}\text { \% cetacean } \\
\text { mortality for } \\
\text { captures } \\
\text { accidental }\end{array}$ \\
\hline $\begin{array}{l}\text { Grande Comore } \\
(\mathrm{n}=340)\end{array}$ & 31 & 63 & Kashkazi (58\%) & 13 & 11 \\
$\begin{array}{l}\text { Mohéli } \\
(\mathrm{n}=69)\end{array}$ & 8.7 & 12 & Kashkazi (63\%) & 5.8 & 25 \\
\hline
\end{tabular}

of relevant sanctions may have resulted in fishers being less honest in the reporting of turtle bycatch. A third possibility is that since turtles are also more easily available on Mohéli (they regularly nest on the beaches), these results could merely reflect a lesser need to capture them from boats.

On Grande Comore, two out of the 10 gillnet fishers interviewed reported captures of dugongs, and another six captures were reported by line fishers during their lifetimes. Six out of these eight dugong captures were reported from the village of Mitsamiouli, north-west Grande Comore, where dugongs may be foraging on extensive seagrass beds (Anasse et al., 2003). Three captures of dugongs were reported by fishers on Mohéli, two of which were in gillnets, even though gillnets were rarely used (Table 1). Gillnets are therefore a clearly identifiable threat to dugongs in the Comoros.

Cetacean captures were more frequently reported on Grande Comore than on Mohéli and mortality for both islands was reported to be fairly low (Table 2). Longlines were the primary gear responsible for cetacean bycatch, although seine nets were involved in one instance. Fishers stated that they tended to release dolphins caught in their gear, since they have no value as food; however, some fishers killed dolphins to stop them from depleting fish stocks. Species reported as bycatch included (from most to least common): spinner dolphin (Stenella longirostris), Indian Ocean bottlenose dolphin (Tursiops aduncus), humpback dolphin (Sousa chinensis) and Risso's dolphin (Grampus griseus). The common dolphin (Delphinus delphis) was also identified by fishers but has not been recorded as present in Comorian waters to date and was probably a misidentification of the spinner dolphin (Kiszka, pers. comm.).

The lack of comprehensive fisheries data for the Union of the Comoros and difficulties in gathering precise empirical historical data from fishers make it unrealistic to extrapolate these figures to generate national bycatch rates. An observer programme to record rates of bycatch in real time would provide such data. In the Comoros, where there is currently no established national system in place to monitor artisanal fisheries, setting up such an observer programme would be costly and logistically complicated. Thus the current priority should be 
to raise awareness among fishers to reduce captures and mortality of non-target species, particularly turtles.

\section{CONCLUSIONS}

Capture of turtles by fishers, particularly on Grande Comore, is of particular concern in the Comoros. Turtle mortality could be reduced by encouraging fishers to not hunt turtles or kill turtles that are caught accidentally. Thus awareness-raising and alternative income generation for fishers are potential means to reduce these threats. Outreach activities were initiated during 2008 by C3Comores, funded by State of the World's Sea Turtles (SWOT) to publicize the need to conserve turtle populations. Gillnets were identified as the primary bycatch-related threat to the dugong, however their use in the Comoros appeared to be minimal and they are already prohibited by Mohéli Marine Park and a number of village associations, although these measures have encountered difficulties in enforcement and sustainability (Hauzer et al., 2008). Cetaceans were rarely captured, and mortality was low.

Acknowledgements: Thanks are due to: Direction Nationale des Ressources Halieutiques, Union of the Comoros for vital assistance in the planning and execution of this study; Université des Comores students for fieldwork on Grande Comore; Hoani Uni Pour la Protection de l'Environnement (HUPPE) for fieldwork on Mohéli: C3 staff and interns and all the Comorian fishers who gave their time and valuable information. We are grateful to two anonymous reviewers who provided valuable comments on an earlier version of this manuscript. Funding for this work was provided by the Gordon and Betty Moore Foundation through Project GloBAL.

\section{REFERENCES}

Abdoulhalik, F.M. (1998) Marine Science Country Profiles Comores. Intergovernmental Oceanographic Commission, Western Indian Ocean Marine Science Association. 35pp

Ahamada, S. (2001) Estimation of Nesting Marine Turtles and Programme for their Conservation in Mohéli islands, Comores. WIOMSA/MARG$\mathrm{I} / 2001 / 03.29 \mathrm{pp}$

Ahamada S., Bijoux J., Bigot L., Cauvin B., Kooonjul M., Maharavo J., Meunier S., Moine-Picard M., Quod J.P. \& Pierre-Louis R. (2004) Status of the Coral Reefs of the South West Indian Ocean Island States. In: Wilkinson C. (ed.) Status of Coral Reefs of the World: 2004 Volume 1. Australian Institute of Marine Science, Townsville, Queensland, Australia. Pp 189-212.

Anasse, F., Ahamada, S., Jantzen, J., Bigot, L., Quod, J.P., Tyack, O., Hamadi, Y., Hamidou, M., Ahamed, S. (2003) Atlas de vulnérabilité des zones coralliennes peu profondes Sud et Nord de la Grande Comore. Projet Régional Environnement - Commission de l'Océan Indien 7. ACP.RPR. $68.51 \mathrm{pp}$

Alfthan, B. \& Davis, P.Z.R. (2006) Dugong Research and Conservation on Mohéli island, Union of the Comoros. Sirenews 46: 13-14.

Ben Mohadji, F. \& Paris B. (Coord.) (2000) Plan d'action pour la Conservation des Tortues Marines en Republique Federale Islamique des Comores. Direction Générale de l'Environnement, Projet Biodiversité (PNUD/FEM/DGE). 36pp

C3-Comores. (2007) Turtle Information Centre and Awareness-Raising Campaign, Mohéli, Comoros. A report submitted to the UNEP/IOSEA Marine Turtle MoU Secretariat. 12pp

Davis, P.Z.R. \& Poonian, C.N.S. (2007) Incidental Capture of the Dugong, Dugong dugon in Gillnets, Mohéli, Union of the Comoros. In: Kiska J., Muir C. (eds.) 1st Regional Workshop on Incidental Catches of Non-targeted Marine Species in the Western Indian Ocean, Workshop proceedings. 13-15th November 2006, Mayotte, France. Pp 58-61.

Fatouma,A.A. (2004) Union of the Comoros. In: Muir, C. (ed.) WWF East African Marine Ecoregion. Towards a Western Indian Ocean Dugong Conservation strategy: The status of Dugongs in the Western Indian Ocean region and Priority Conservation actions. WWF, Dar es Salaam, Tanzania. Pp 48-49.

Hauzer, M., Poonian, C., Moussa Iboura, C. (2008) Mohéli Marine Park, Comoros - Successes and Challenges of the Co-management Approach. In: Obura, D.O., Tamelander, J, \& Linden, O. (Eds.) Ten years after bleaching - facing the consequences of climate change in the Indian Ocean. CORDIO Status Report 2008. Coastal Oceans Research and Development in the Indian Ocean/Sida-SAREC. Mombasa. http://www.cordioea.org

Kiszka, J., Breysse, O., Vely, M., \& Boinali, K. (2006) Marine mammals around the Comoros archipelago 
(Mozambique Channel): recent records and review of available information. SC-58-O6. International Whaling Committee Scientific Commission meeting 2006.

Lewison, R.L., Crowder, L.B., Read, A.J. \& Freeman, S.A. (2004) Understanding impacts of fisheries bycatch on marine megafauna. Trends in Ecology and Evolution 19: 598-604.

Mortimer J. (1993) Marine Turtles in the Comoros Federal Islamic Republic: Their Status and Recommendations for their Management. University of Florida. 43pp

Mortimer, J.A. \& Donnelly, M. (2008) Eretmochelys imbricata. In: IUCN 2008. 2008 IUCN Red List of Threatened Species. www.iucnredlist.org. Downloaded on 27 February 20
Richmond, M.D., (ed.) (2002) A Field Guide to the Seashores of Eastern Africa and the Western Indian Ocean Islands. Sida/SAREC - UDSM 461pp.

Seminoff, J.A. (2004) Chelonia mydas. In: IUCN 2008. 2008 IUCN Red List of Threatened Species. www.iucnredlist.org. Downloaded on 27 February 2009.

UNEP (2002) L'Afrique Orientale Atlas des Ressources Cotieres. United Nations Environment Programme, Nairobi. 154pp

Union des Comores (2005) Document de Stratégie de Croissance et de Réduction de la Pauvreté. Document Intérimaire Actualise. 138pp. 


\section{Appendix 1. Rapid assessment survey datasheets}

Rapid Assessment Protocol -- Long Form

Type of Gear

Date

To be completed for each fisher interviewed.

If the fisher uses multiple gears, complete a separate form for each type that is of interest to this study

Country

Port or community name

Interviewer

Interviewee

How many boats (using this gear type) are actively used in the community?

How many total boats (all gear types combined) are actively used in the community?

Boat specifications (for this gear type)

Type

Motorized? (circle one)

Do you always land at this port?

If not, what percentage of fishing trips do you land here?

outboard HP of motor

Which other ports do you visit?

Haul Information

Gear Characteristics (fill out section for gear type listed at top of form)

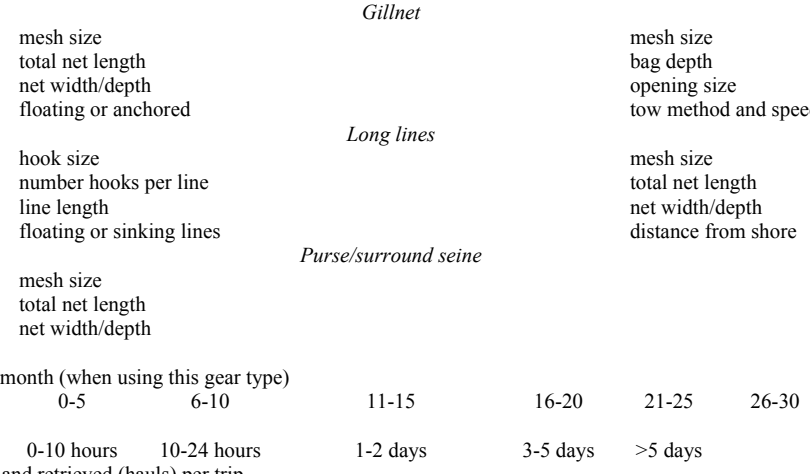

Trawl or towed nets

Beach seine

total net length

net width/depth

number hooks per line
line length

Where do you fish? (Draw locations on map. Indicate areas you fish most often, sometimes, rarely)

Are there areas where fishing is not allowed? (Draw locations on map)

Average Distance from shore for hauls (for this gear type)

How does location and/or distance from shore change among seasons?

Time of day of sets

Duration of trawls/sets (for this gear type)

Time of day of hauls

Depth of hauls (for this gear type)

Months fished

In what season do you have the most fishing effort?

Catch Information

Species Caught

Do you ever catch sea turtles? YES NO

Average daily catch (in xx)

Which species?

If so, on average how many in a month (Record separate answers for each species)?

$\begin{array}{lllll}0 & <1 & 1-5 & 6-10 & >10\end{array}$

$\begin{array}{cccc}\text { How many in the last year (Record separate answers for each species)? } & \\ 0 & <1 & 6-10 & >10\end{array}$

Est. \#

$\begin{array}{cc}0 & <1 \\ \text { In what months or seasons do you catch sea turtles? }\end{array}$

$>10$

Est. \#

In what months do you most commonly catch them?

In what general location do you catch them (including distance offshore)?

If you catch one, what do you do with it?

Do you ever catch dugongs?

If so, on average how many in a month?

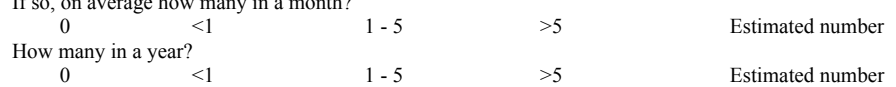

In what months or seasons do you most commonly catch dugongs?

In what general location do you catch them (including distance offshore)?

If you catch one, what do you do with it?

Do you ever catch dolphins or whales?

YES NO

If so, on average how many in a month (Record separate answers for each species)? Which species?

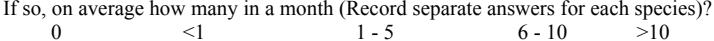

How many in the last year (Record separate answers for each species)?

$\begin{array}{ccc}0 & <1 & 1-5 \\ \text { what months or seasons do you catch whales or dolphins? }\end{array}$

$>10$

In what months or seasons do you catch whales or dolp
In what months do you most commonly catch them?

In what months do you most commonly catch them?
In what general location do you catch them (including distance offshore)?

If you catch one, what do you do with it?

Additional Comments

\section{$\mathbf{Y}$}

FOR INTERVIEWER ONLY

Please answer the following questions to help us assess the protocol.

Please comment on challenges encountered conducting the survey and solutions to deal with those challenges

Questions for which it was difficult to obtain concrete answers

Do you have suggestions for wording changes on those questions?

Please comment on the general perception to the truthfulness of answers. For example,

Were the fishers open and honest or did they seem uncomfortable answering questions?

If they were uncomfortable, which specific questions? 


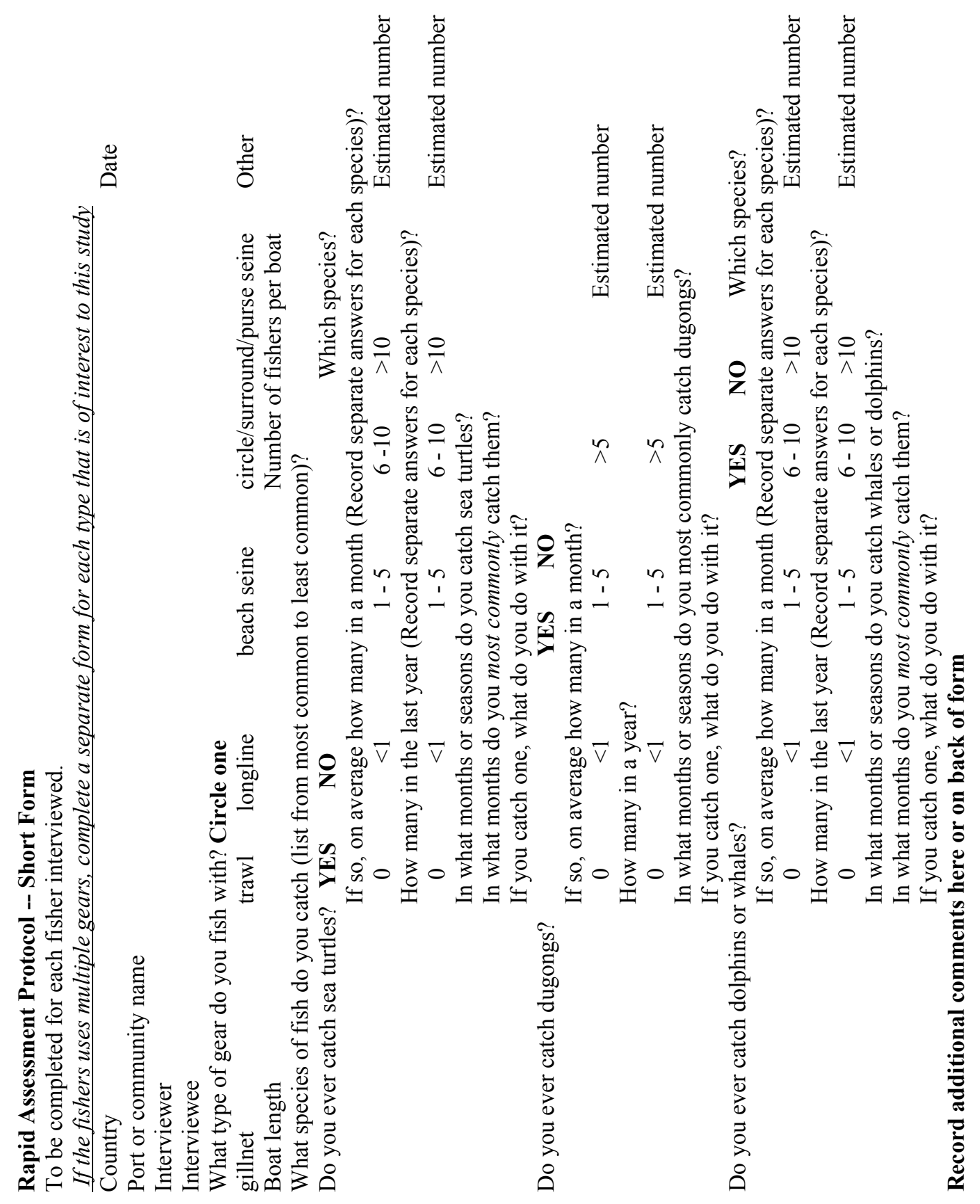




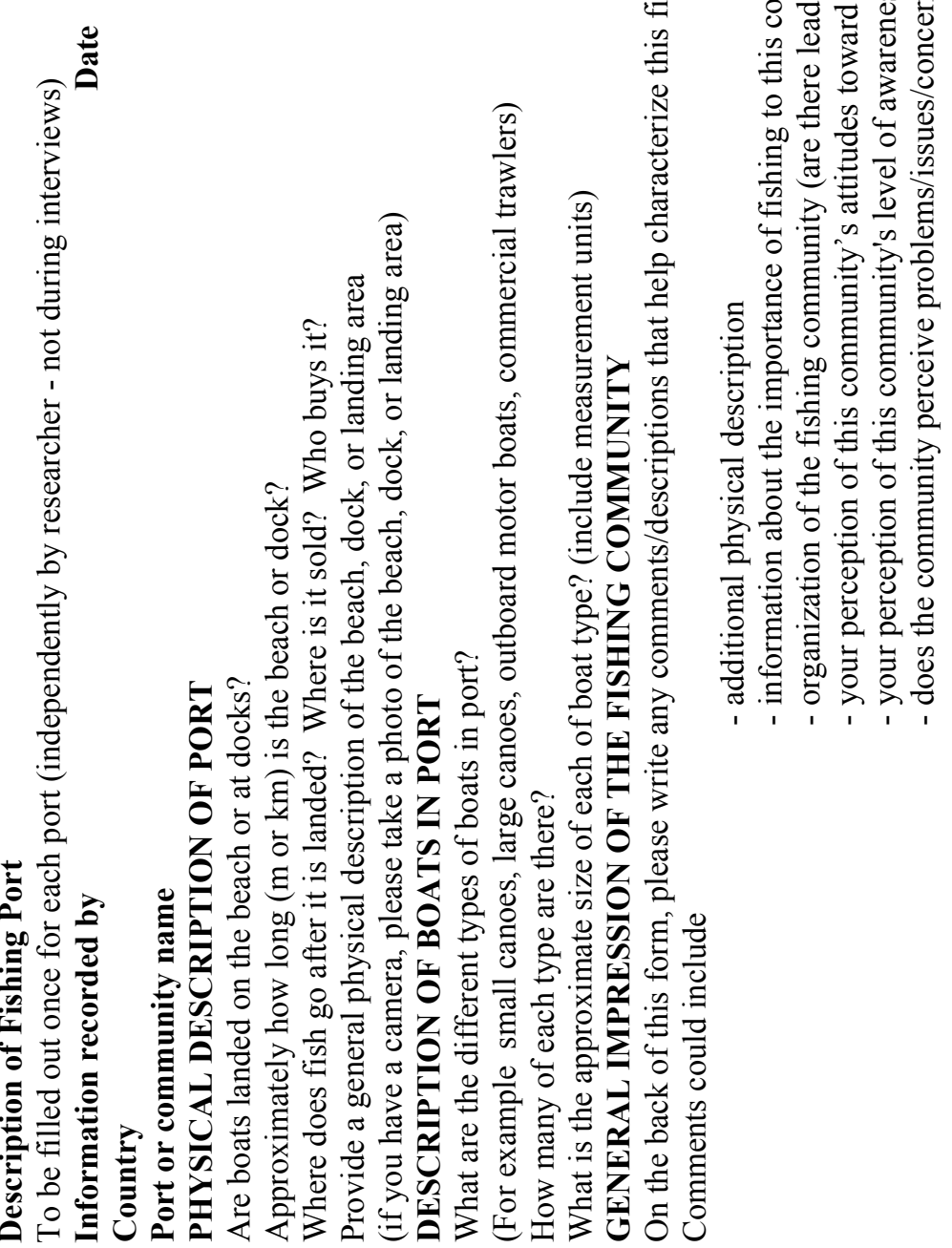


